\title{
FAKTOR ASUPAN ZAT GIZI YANG BERHUBUNGAN KADAR ASAM URAT DARAH WANITA POSTMENOPAUSE
}

\author{
Ade Mulyasari, Fillah Fithra Dieny ${ }^{*}$ \\ Program Studi Ilmu Gizi Fakultas Kedokteran Universitas Diponegoro \\ Jl.Dr.Sutomo No.18, Semarang, Telp (024) 8453708, Email : gizifk@ undip.ac.id
}

\begin{abstract}
Background : Hyperuricemia occurs in women after menopause due to decreased in estrogen levels. Animal protein was convinced to be the cause of elevated levels of blood uric acid, while the intake of nutrients such as folic acid, vitamin $C$ and calcium have uricosuric effect. Sufficient fluid intakes could reduce the uric acid levels with the function as disposal media of uric acid.

Objective : This study aimed to examine the associations between intake of nutrients such as protein, folic acid, vitamin $C$, calcium and fluid with blood uric acid levels in postmenopausal women.

Methods : Observational study with analytic descriptive design using cross sectional method in postmenopausal women at Ngemplak Simongan and Bongsari, Semarang. Subject of 68 people obtained by simple random sampling. BMI data measured using anthropometric measurements, nutrient intake history of protein, vitamin $C$, folic acid and calcium was collected by using a semi-Quantitatives Food Frequency Questionnaire. Twenty four hours Recall was conducted to determine fluid intakes. Colorimetric method was used to analyze the blood uric acid levels. Test of normality using the Kolmogorov-Smirnov. Bivariate analysis using correlation test, multivariate analysis using Multiple Linear Regression test.

Results : Hyperuricemia subject was found in 8 people $(11,8 \%)$. The most of subjects had protein intake more than recommendation. The overall subject had sufficient intake of folic acid and vitamin $C$, while 86,8\% of subjects had inadequate calcium intake. Daily fluid intake less than $1500 \mathrm{ml} /$ day was found in 57,4\% subjects. Intake of animal protein, vitamin $C$, calcium and fluids were associated with blood uric acid levels $(p<0,05)$. While multivariate analysis results showed that intake of animal protein, vitamin $C$ and calcium had most effect on blood uric acid level in postmenopausal women (Adjusted $R$ Square $=0,298$ ).

Conclusions : Excessive animal protein intake and inadequate intake of vitamin $C$ and calcium were associated with increased of blood uric acid levels in postmenopausal women.
\end{abstract}

Keywords : blood uric acid, postmenopausal, protein intake

\begin{abstract}
ABSTRAK
Latar Belakang : Hiperurisemia terjadi pada wanita setelah menopause akibat adanya penurunan kadar estrogen. Protein hewani diyakini sebagai penyebab peningkatan kadar asam urat dalam darah, sedangkan asupan zat gizi seperti asam folat, vitamin $C$ dan kalsium memiliki efek urikosurik. Konsumsi cairan yang cukup dapat menurunkan kadar asam urat darah dengan berfungsi sebagai media pembuangan asam urat.
\end{abstract}

Tujuan : Penelitian ini bertujuan untuk menguji hubungan asupan zat gizi seperti protein, asam folat, vitamin $C$, kalsium dan cairan dengan kadar asam urat darah wanita postmenopause.

Metode : Penelitian observasional dengan jenis penelitian deskriptif analitik menggunakan metode cross sectional pada wanita postmenopause di Kelurahan Ngemplak Simongan dan Bongsari Kota Semarang. Subjek sebanyak 68 orang didapatkan dengan cara random sampling. Data IMT didapatkan melalui pengukuran antropometri, data asupan protein, vitamin $C$, asam folat serta kalsium diperoleh melalui wawancara menggunakan Semi-Quantitatives Food Frequency Questionnaire. Recall 24 jam dilakukan untuk mengetahui asupan cairan. Metode kolorimetri digunakan untuk menganalisis kadar asam urat darah. Uji normalitas menggunakan Kolmogorov-Smirnov. Analisis bivariat menggunakan uji Korelasi, analisis multivariat menggunakan uji Regresi Linier Ganda.

Hasil : Subjek hiperurisemia ditemukan sebanyak 8 orang (11,8\%). Hampir keseluruhan asupan protein subjek lebih dari anjuran. Asupan asam folat dan vitamin C sebagian besar subjek cukup, sedangkan sebanyak 86,8\% subjek memiliki asupan kalsium kurang. Asupan cairan sehari kurang dari 1500ml/hari ditemukan pada 57,4\% subjek. Asupan protein hewani, vitamin $C$, kalsium dan cairan berhubungan dengan kadar asam urat darah $(p<0,05)$. Sementara hasil analisis multivariat menunjukkan bahwa asupan protein hewani, vitamin $C$ dan kalsium paling berpengaruh dengan kadar asam urat darah wanita postmenopause (Adjusted $R$ Square = 0,298).

Kesimpulan : Asupan protein hewani yang berlebih dan asupan vitamin C serta kalsium yang kurang, berhubungan dengan peningkatan kadar asam urat darah pada wanita postmenopause.

Kata kunci : asam urat darah, postmenopause, asupan protein

\section{PENDAHULUAN}

Penyakit gout merupakan salah satu penyakit degeneratif yang ditandai dengan adanya hiperurisemia atau peningkatan kadar asam urat dalam darah. ${ }^{1}$ Pada sebagian besar penelitian epidemiologi menyebutkan sebagai hiperurisemia

${ }^{*}$ Penulis Penanggungjawab 
jika kadar asam urat serum orang dewasa lebih dari $7,0 \mathrm{mg} / \mathrm{dl}$ pada laki-laki dan lebih dari $6,0 \mathrm{mg} / \mathrm{dl}$ pada perempuan. ${ }^{2}$ Hiperurisemia yang terjadi dapat menimbulkan penumpukan kristal asam urat. Gout akan terjadi jika kristal asam urat tersebut berada dalam cairan sendi. ${ }^{1}$ Kristal urat juga dapat menjadi penyebab terjadinya batu ginjal. ${ }^{3}$

Penelitian National Health and Nutrition Examination Survey (NHANES) di Amerika Serikat pada tahun 2007-2008 menunjukkan prevalensi penyakit gout sebesar 3,9\% dengan prevalensi hiperurisemia sebesar 21,4\%. ${ }^{1}$ Prevalensi hiperurisemia di Asia Tenggara lebih besar daripada di Amerika Serikat. Penelitian di Taiwan menunjukkan peningkatan prevalensi gout sebesar 4,74\% dan kejadian hiperurisemia pada lansia sebesar 36\%. Prevalensi hiperurisemia di Indonesia sendiri masih belum diketahui dengan pasti, namun sebuah survei epidemiologik kerjasama WHOCOPCORD yang dilakukan di Bandungan, Jawa Tengah dengan 4.683 sampel berusia 15-45 tahun didapatkan bahwa prevalensi gout pada wanita sebesar $11,7 \% .^{4}$

Peningkatan kadar asam urat darah akan terjadi pada wanita setelah menopause akibat adanya penurunan kadar estrogen yang berperan dalam peningkatan ekskresi asam urat melalui urin. ${ }^{5}$ Sehingga risiko hiperurisemia pada wanita akan meningkat ketika memasuki usia menopause. Data NHANES menunjukkan prevalensi hiperurisemia pada koresponden kelompok usia lebih dari 65 tahun sebesar $21,6 \%$ pada wanita dan sisanya pada pria sebesar $21,2 \% .{ }^{1}$ Penurunan sekresi estrogen yang terjadi saat menopause juga dapat menyebabkan penumpukan lemak secara bertahap pada jaringan viseral abdomen dan menghasilkan obesitas sentral. ${ }^{6}$ Obesitas dapat memicu peningkatan kadar asam urat dalam darah akibat adanya penurunan ekskresi kadar asam urat melalui ginjal. $^{7}$

Asupan makanan juga dapat mempengaruhi kadar asam urat darah. Beberapa zat gizi seperti protein, asam folat, vitamin $\mathrm{C}$, kalsium dan cairan diyakini memiliki hubungaan dengan peningkatan kadar asam urat darah. Namun penelitian terdahulu terkait hal tersebut masih menunjukkan hasil yang berbeda-beda. Penderita hiperurisemia biasanya dianjurkan untuk menurunkan asupan protein mereka sebagai terapi penurunan kadar asam urat darah, karena adanya peningkatan asupan protein akan mempercepat produksi purin endogenous yang akan memicu pemecahan purin dalam tubuh dan meningkatkan kadar asam urat darah. Hal tersebut bertolak belakang dengan beberapa penelitian di Cina yang menunjukkan bahwa asupan protein total tidak memiliki pengaruh dengan kadar asam urat darah, dimana asupan protein hewani khususnya daging dan seafood lebih berperan dengan peningkatan risiko hiperurisemia. ${ }^{8}$ Hal ini sesuai dengan studi cross sectional di kota Batu, Malang yang menunjukkan bahwa asupan protein hewani yang tinggi memiliki pengaruh yang signifikan dengan risiko gout. ${ }^{9}$

Selama ini protein nabati dan beberapa sayuran sumber purin diyakini sebagai penyebab peningkatan asam urat sehingga masyarakat cenderung akan membatasi asupan kacangkacangan, bayam, jamur dan kembang kol sebagai usaha untuk mencegah hiperurisemia. Namun studi pada pria di Amerika Serikat menunjukkan hal sebaliknya, dimana asupan protein nabati yang tinggi akan menurunkan risiko terjadinya gout sebanyak $27 \% .^{10}$

Asupan cairan yang tinggi juga diyakini dapat menurunkan kadar asam urat, dimana cairan dapat berfungsi sebagai pelarut dan media pembuangan berbagai hasil metabolisme. ${ }^{11}$ Beberapa penelitian masih belum menunjukkan hubungan yang signifikan antara asupan cairan dan kadar asam urat darah. Seperti penelitian yang dilakukan pada 40 orang subjek berusia 50-60 tahun di Kecamatan Gajah Mungkur Semarang menunjukkan tidak adanya hubungan secara statistik namun diketahui bahwa adanya kadar asam urat yang lebih rendah pada subjek dengan asupan cairan lebih dari $2000 \mathrm{ml}^{.12}$

Kalsium merupakan salah satu zat gizi yang memiliki efek urikosurik. Sumber utama kalsium berasal dari susu dan hasil olahannya yang memiliki kadar purin rendah $<100 \mathrm{mg} / 100$ gram bahan makanan. Kalsium dapat meningkatkan ekskresi asam urat dan bertindak sebagai prekusor enzim xantin dalam mekanisme protein. ${ }^{13}$ Studi cross-sectional di Belanda tahun 2006 menemukan adanya kadar asam urat darah yang lebih rendah sebesar $22 \mathrm{mmol} / \mathrm{dl}(0,369 \mathrm{mg} / \mathrm{dl})$ pada subjek dengan asupan kalsium $1200 \mathrm{mg} / \mathrm{hari}$. Namun studi intervensi lain menunjukkan hasil yang tidak signifikan pada suplementasi kalsium terhadap asam urat darah. ${ }^{14}$

Asam folat dan vitamin C merupakan zat gizi lain yang juga diyakini memiliki efek urikosurik. Hasil penelitian di Korea menemukan adanya asupan folat yang rendah pada subjek hiperurisemia. ${ }^{15}$ Suplementasi asam folat sebesar 80 $\mathrm{mg} /$ hari dapat menurunkan kadar asam urat melalui penghambatan aktivitas enzim xantin oksidase yang berperan dalam produksi asam urat. ${ }^{16}$ Penelitian kohort yang dilakukan pada 51.529 pria di Amerika 
Serikat menunjukkan suplementasi vitamin C sebesar $500 \mathrm{mg} / \mathrm{hari}$ selama dua bulan dapat menurunkan kadar asam urat darah sebesar 0,5 $\mathrm{mg} / \mathrm{dl}$. Vitamin C diyakini memiliki efek urikosurik yang disebabkan adanya kompetisi absorbs asam urat dan vitamin $\mathrm{C}$ melalui anion exchange transport system di tubulus proksimal. ${ }^{17}$

Berdasarkan latar belakang diatas peneliti tertarik meneliti hubungan antara berbagai asupan zat gizi seperti protein, asam folat, vitamin $\mathrm{C}$, kalsium dan cairan dengan kadar asam urat wanita postmenopause.

\section{METODE PENELITIAN}

Penelitian dilaksanakan di wilayah kerja Puskesmas Ngemplak Simongan (Kelurahan Ngemplak Simongan dan Kelurahan Bongsari, Kecamatan Semarang Barat), Kota Semarang pada bulan Juni - Juli 2014. Penelitian ini termasuk dalam lingkup penelitian gizi masyarakat dan merupakan penelitian observasional dengan desain cross-sectional. Populasi target dalam penelitian ini seluruh wanita postmenopause yang berada di Kota Semarang, sedangkan populasi terjangkau dalam penelitian ini adalah wanita postmenopause yang bertempat tinggal di wilayah kerja Puskesmas Ngemplak Simongan (Kelurahan Ngemplak Simongan dan Kelurahan Bongsari, Kecamatan Semarang Barat) Kota Semarang. Kriteria inklusi meliputi wanita postmenopause (tidak haid selama $\geq 1$ tahun), berusia 45-65 tahun, dapat berkomunikasi dengan baik, tidak mengkonsumsi obat-obatan penurun asam urat, bersedia mengikuti penelitian dengan mengisi lembar formulir Informed Consent. Besar sampel dihitung dengan rumus perkiraan menggunakan estimasi proporsi suatu populasi dengan tingkat kemaknaan $\left(Z_{\alpha}\right) 95 \%$ dan didapatkan sampel minimal sebanyak 66 orang dengan koreksi besar sampel sebanyak 7 orang. Pengambilan sampel dengan cara acak sederhana (simple random sampling), didapatkan sebanyak 73 orang, namun sebanyak 5 orang mengundurkan diri sehingga jumlah keseluruhan sampel sebanyak 68 orang.

Variabel dalam penelitian ini meliputi variabel bebas berupa asupan protein (protein total, protein hewani, dan protein nabati), asam folat, vitamin $\mathrm{C}$, kalsium dan cairan, dan variabel terikat yaitu kadar asam urat darah, serta variabel perancu berupa Indeks Massa Tubuh (IMT).

Data karakteristik subjek meliputi nama, usia, alamat, pekerjaan, lama menopause, aktifitas fisik, riwayat penyakit, konsumsi suplemen dan obat-obatan serta antropometri meliputi berat badan dan tinggi badan untuk menghitung IMT. Data karakteristik subjek diperoleh menggunakan kuesioner dan data antropometri diukur dengan timbangan digital dan microtoise. Asupan protein, asam folat, vitamin $\mathrm{C}$ dan kalsium diperoleh melalui wawancara menggunakan formulir SemiQuantitatives Food Frequency Questinnaire. Data asupan makanan yang diperoleh (ukuran rumah tangga/URT) dikonversikan dalam gram. Hasil yang diperoleh dianalisis menggunakan program nutrisurvey kemudian dibandingkan dengan AKG 2013. Adapun angka kecukupan gizinya adalah 57 gram protein per hari untuk wanita usia 50-64 tahun; 2-3 porsi protein hewani (14-21 gram per hari); $2-3$ porsi protein nabati (10-15 gram per hari); $150 \mu \mathrm{g}$ per hari asam folat; $75 \mathrm{mg}$ per hari vitamin C; 1000-1200 mg per hari kalsium. Data asupan cairan dari makanan diperoleh melalui recall $1 \times 24$ jam dan diolah menggunakan software nutrisurvey, ditambahkan asupan cairan yang diperoleh dari minuman dan kuah. Data asupan cairan yang diperoleh (ukuran rumah tangga/URT) dikonversikan ke milliliter. Angka kecukupan asupan cairan lansia adalah $\geq 1500 \mathrm{ml}$ per hari. ${ }^{18}$

Asupan protein dikategorikan menjadi < 57 gram dan $\geq 57$ gram. Asupan protein hewani dikategorikan cukup jika berada pada rentang 14-21 gram per hari, dan lebih jika > 21 gram per hari. Kategori cukup asupan protein nabati jika berada pada rentang $10-15$ gram per hari dan asupan $>15$ gram per hari dikategorikan lebih. Asupan asam folat $\geq 150 \mu \mathrm{g}$ per hari dikategorikan cukup dan < $150 \mu \mathrm{g}$ dikategorikan kurang. Asupan vitamin C cukup $75 \mathrm{mg}$ per hari dan kurang jika $<75 \mathrm{mg}$ per hari. Kategori cukup asupan kalsium jika berada pada rentang $1000-1200 \mathrm{mg}$ per hari dan dikategorikan kurang jika $<1000 \mathrm{mg} /$ hari. Asupan cairan cukup $\geq 1500 \mathrm{ml}$ per hari dan kurang bila < $1500 \mathrm{ml}$ per hari.

Kadar asam urat didefinisikan sebagai jumlah asam urat dalam darah subjek setelah berpuasa selama 10-12 jam yang diukur dengan metode kolorimetri oleh petugas laboratorium, dibedakan menjadi tinggi bila $>6,0 \mathrm{mg} / \mathrm{dl}$, normal bila $2,6-6,0 \mathrm{mg} / \mathrm{dl}$, dan rendah bila $<2,6 \mathrm{mg} / \mathrm{dl} .{ }^{4}$ IMT subjek diklasifikasikan berdasarkan Asia Pasifik dimana IMT $<18,5 \quad \mathrm{~kg} / \mathrm{m}^{2}$ termasuk underweight, $18,5-22,9 \mathrm{~kg} / \mathrm{m}^{2}$ tergolong normal, 23 $24,9 \mathrm{~kg} / \mathrm{m}^{2}$ tergolong overweight, $25-29,9$ tergolong obesitas I dan $>30 \mathrm{~kg} / \mathrm{m}^{2}$ termasuk obesitas II. ${ }^{19}$

Analisis data dilakukan dengan menggunakan program Statistical package for the social science (SPSS) for windows release 16. Analisis univariat digunakan untuk menggambarkan data identitas subjek, jumlah 
asupan protein, asam folat, vitamin $\mathrm{C}$, kalsium, cairan, IMT dan kadar asam urat. Data tersebut diuji kenormalannya dengan menggunakan uji Kolmogorov-Smirnov. Analisis bivariat untuk melihat hubungan masing-masing asupan protein, asam folat, vitamin $\mathrm{C}$, kalsium, dan cairan dengan kadar asam urat menggunakan uji korelasi Pearson untuk data normal dan uji korelasi Spearman untuk data tidak normal. Variabel yang dimasukkan dalam analisis multivariat menggunakan Regresi Linier
Ganda adalah variabel yang berdasarkan analisis bivariat mempunyai nilai $\mathrm{p}<0,25$.

\section{HASIL PENELITIAN}

Jumlah subjek dalam penelitian ini sebanyak 68 orang wanita postmenopause. Tabel 1 menunjukkan gambaran umum nilai minimum, maksimum, rerata dan simpang baku untuk variabel usia, lama menopause, IMT, kadar asam urat dan asupan zat gizi subjek.

Tabel 1. Gambaran Umum Subjek

\begin{tabular}{llll}
\hline \multicolumn{1}{c}{ Karakteristik } & \multicolumn{1}{c}{ Minimum } & Maximum & \multicolumn{1}{c}{ Rerata \pm Simpang Baku } \\
\hline Usia Responden (tahun) & 49 & 64 & $55,74 \pm 3,41$ \\
Lama Menopause (tahun) & 2 & 15 & $6,56 \pm 3,88$ \\
IMT (kg/m ${ }^{2}$ ) & 18,0 & 41,0 & $25,38 \pm 4,12$ \\
Kadar Asam Urat (mg/dl) & 2,4 & 6,4 & $4,08 \pm 1,13$ \\
Asupan Protein (gr/hari) & 23,00 & 172,00 & $75.79 \pm 32,28$ \\
Asupan Protein Hewani (gr/hari) & 7,50 & 133,90 & $30,54 \pm 19,09$ \\
Asupan Protein Nabati (gr/hari) & 14,30 & 110,00 & $45,90 \pm 22.28$ \\
Asupan Asam Folat ( $\mu$ g) & 91,20 & 288,10 & $163,61 \pm 45,57$ \\
Asupan Vitamin C (mg) & 15,00 & 217,30 & $100,50 \pm 50,72$ \\
Asupan Kalsium (mg) & 215,00 & 1392,00 & $662,19 \pm 275,14$ \\
Asupan Cairan (mg) & 750,10 & 2437,80 & $1597,60 \pm 388,98$ \\
\hline
\end{tabular}

Berdasarkan tabel 1, usia responden berada pada rentang 49-64 tahun dengan rerata 55,74 tahun. Subjek memiliki kadar asam urat maksimum sebesar $6,4 \mathrm{mg} / \mathrm{dl}$. Rerata asupan protein subjek sebesar 75,79 $\pm 32,28$ dengan asupan maksimal sebanyak 172 gr/hari. Asupan protein hewani dan nabati maksimal pada responden masing-masing sebesar $133,90 \quad$ gr/hari $(30,54 \pm 19,09)$ dan 110 gr/hari $(45,90 \pm 22,28)$. Maksimum asupan vitamin $\mathrm{C}$ responden sebesar $217,30 \mathrm{mg} /$ hari. Rerata asupan cairan subjek sehari cukup dari anjuran sebesar $1500 \mathrm{ml} / \mathrm{hari}(1597,60 \pm$ 388,98).

\section{Karakteristik Subjek}

Hasil penelitian menunjukkan usia subjek sebagian besar berada pada kisaran 46-55 tahun $(54,4 \%)$ dengan rerata $55,74 \pm 3,41$. Responden memiliki lama menopause 1-10 tahun ditemukan sebanyak 58 orang $(85,3 \%)$. Pekerjaan responden sebagian besar sebagai ibu rumah tangga $(70,6 \%)$. Sebanyak 29 orang subjek penelitian memiliki kisaran IMT $25-29,9 \mathrm{~kg} / \mathrm{m}^{2}(42,6 \%)$. Hal ini menunjukkan bahwa subjek penelitian terkategori obesitas I. Kadar asam urat subjek sebagian besar berada pada kategori normal $(88,2 \%)$, namun ditemukan sebanyak 8 orang subjek dengan hiperurisemia $(11,8 \%)$.

Tabel 2. Distribusi Frekuensi Karakteristik Subjek

\begin{tabular}{lll}
\hline Karakteristik & Frekuensi (n) & Persentase (\%) \\
\hline Usia & & \\
- 46-55 tahun & 37 & 54,4 \\
- 56-65 tahun & 31 & 45,6 \\
Lama Menopause & & \\
- $\quad$ 10 tahun & 58 & 85,3 \\
- > 10 tahun & 10 & 14,7 \\
Pekerjaan & & \\
- Karyawan & 9 & 13,2 \\
- Ibu Rumah Tangga & 48 & 70,6 \\
- Wiraswasta & 11 & 16,2 \\
IMT (kg/m ${ }^{2}$ ) & & \\
- Underweight $<18,5$ & 1 & 1,5 \\
- Normal 18,5 - 22,9 & 10 & 14,7 \\
- Overweight 23-24,9 & 21 & 30,9 \\
- Obesitas I 25 - 29,9 & 29 & 42,6 \\
- Obesitas II $\geq 30$ & 7 & 10,3 \\
Kadar Asam Urat (mg/dl) & & 88,2 \\
- Normal & 60 & 11,8 \\
- Tinggi & 8 &
\end{tabular}




\section{Asupan Zat Gizi Wanita Postmenopause}

Distribusi frekuensi asupan zat gizi wanita postmenopause yang meliputi asupan protein total, protein hewani, protein nabati, asam folat, vitamin $\mathrm{C}$, kalsium dan cairan dapat dilihat pada tabel 3 .

Tabel 3. Distribusi Frekuensi Asupan Zat Gizi

\begin{tabular}{|c|c|c|}
\hline Variabel & Frekuensi (n) & Persentase (\%) \\
\hline \multicolumn{3}{|l|}{ Asupan Protein Total } \\
\hline - $<57$ gram/hari & 22 & 32,4 \\
\hline$-\quad \geq 57$ gram $/$ hari & 46 & 67,6 \\
\hline \multicolumn{3}{|l|}{ Asupan Protein Hewani } \\
\hline - Cukup (14-21 gram/hari) & 19 & 27,9 \\
\hline - Lebih (> 21 gram/hari) & 49 & 72,1 \\
\hline \multicolumn{3}{|l|}{ Asupan Protein Nabati } \\
\hline - Cukup (10 - 15 gram/hari) & 1 & 1,5 \\
\hline - Lebih (> 15 gram/hari) & 67 & 98,5 \\
\hline \multicolumn{3}{|l|}{ Asupan Asam Folat } \\
\hline - Kurang $(<150 \mu \mathrm{g} / \mathrm{hari})$ & 25 & 36,8 \\
\hline - Cukup ( $\geq 150 \mu \mathrm{g} / \mathrm{hari})$ & 43 & 63,2 \\
\hline \multicolumn{3}{|l|}{ Asupan Vitamin C } \\
\hline - Kurang (< 75 mg/hari) & 23 & 33,8 \\
\hline - Cukup ( $\geq 75$ mg/hari) & 45 & 66,2 \\
\hline \multicolumn{3}{|l|}{ Asupan Kalsium } \\
\hline - Kurang (< 1000 mg/hari) & 59 & 86,8 \\
\hline - Cukup $(1000-1200 \mathrm{mg} / \mathrm{hari})$ & 9 & 13,2 \\
\hline \multicolumn{3}{|l|}{ Asupan Cairan } \\
\hline - Kurang (<1500 ml/hari) & 29 & 42,6 \\
\hline - Cukup ( $\geq 1500 \mathrm{ml} / \mathrm{hari})$ & 39 & 57,4 \\
\hline
\end{tabular}

Tabel 3 menunjukkan bahwa lebih dari separuh subjek memiliki asupan protein lebih dari AKG sebesar 57 gr/hari (67,6 \%). Sebanyak 49 orang responden memiliki asupan protein hewani $>21$ gram/hari, dan hampir semua responden memiliki asupan protein nabati lebih dari 15 gram/hari $(98,5 \%)$. Subjek penelitian sebagian besar memiliki asupan asam folat dan vitamin $\mathrm{C}$ yang cukup, namun memiliki asupan kalsium dan cairan yang kurang. Asupan kalsium rendah ditemukan pada 59 orang subjek $(86,8 \%)$. Sebanyak 29 orang subjek memiliki asupan cairan kurang dari $1500 \mathrm{ml} / \mathrm{hari}(57,4 \%)$.

\section{Faktor-faktor yang Berhubungan dengan Kadar Asam Urat Darah Wanita Postmenopause}

Berdasarkan uji normalitas didapatkan data asupan protein total, asam folat dan cairan berdistribusi normal, sedangkan data IMT, asupan protein hewani, protein nabati, vitamin $\mathrm{C}$, dan kalsium berdistribusi tidak normal. Faktor-faktor yang berhubungan dengan kadar asam urat darah wanita postmenopause ditunjukkan pada tabel 4 .

Tabel 4 Faktor-Faktor yang Berhubungan dengan Kadar Asam Urat Darah Wanita Postmenopause

\begin{tabular}{lll}
\hline Variabel & $\mathbf{r}$ & $\boldsymbol{P}$ \\
\hline Asupan Protein Total & 0,043 & $0,729^{\mathrm{NS}}$ \\
Asupan Protein Hewani & 0,322 & $0,007^{\mathrm{S}}$ \\
Asupan Protein Nabati & $-0,196$ & $0,110^{\mathrm{NS}}$ \\
Asupan Asam Folat & $-0,026$ & $0,833^{\mathrm{NS}}$ \\
Asupan Vitamin C & $-0,311$ & $0,010^{\mathrm{S}}$ \\
Asupan Kalsium & $-0,295$ & $0,014^{\mathrm{S}}$ \\
Asupan Cairan & $-0,322$ & $0,007^{\mathrm{S}}$ \\
IMT & 0,021 & $0,865^{\mathrm{NS}}$ \\
\hline
\end{tabular}

Catatan: S : Significant $(\mathrm{p}<0,05)$

NS : Not Significant

Hasil penelitian menunjukkan bahwa asupan protein hewani, vitamin $\mathrm{C}$, kalsium dan cairan memiliki hubungan dengan kadar asam urat darah wanita postmenopause. Protein hewani berhubungan positif dengan kadar asam urat wanita post menopause dengan nilai $\mathrm{r}=0,322$ dan nilai $p=$ 0,007 yang artinya semakin tinggi asupan protein hewani maka kadar asam urat darah akan semakin 
tinggi pula. Sementara itu asupan vitamin $\mathrm{C}(\mathrm{r}=-$ $0,311 ; p=0,010)$, kalsium $(\mathrm{r}=-0,295 ; p=0,014)$ dan cairan $(\mathrm{r}=-0,322 ; p=0,007)$ berhubungan negatif dengan kadar asam urat darah, artinya semakin tinggi asupan vitamin $\mathrm{C}$, kalsium dan cairan maka akan semakin rendah kadar asam urat darah wanita postmenopause.

\section{Faktor-faktor yang Paling Berhubungan dengan Kadar Asam Urat Darah Wanita Postmenopause}

Variabel yang dimasukan dalam hasil analisis multivariat dengan nilai $p<0,25$ pada analisis bivariat yaitu asupan protein hewani, protein nabati, vitamin $\mathrm{C}$, kalsium dan cairan. Hasil uji regresi linier dapat dilihat pada tabel 5 berikut ini.

Tabel 5. Hasil Analisis Multivariat Regresi Linier Ganda

\begin{tabular}{lcc}
\hline \multicolumn{1}{c}{ Variabel } & Koefisien & $\boldsymbol{P}$ \\
\hline Asupan Protein Hewani & 0,020 & 0,002 \\
Asupan Vitamin C & $-0,005$ & 0,039 \\
Asupan Kalsium & $-0,001$ & 0,019 \\
\hline
\end{tabular}

Persamaan yang didapatkan dari hasil regresi linier tersebut untuk memprediksi asam urat darah adalah $\mathrm{y}=5,634+0,020$ (asupan protein hewani) - 0,005 (asupan vitamin C) - 0,001 (asupan kalsium), artinya setiap peningkatan asupan protein hewani sebanyak 1 gram/hari akan terjadi peningkatan kadar asam urat darah sebanyak 0,020 gram/dl. Setiap peningkatan asupan vitamin $C$ dan kalsium sebanyak $1 \mathrm{mg} /$ hari akan menurunkan kadar asam urat darah masing-masing sebanyak 0,005 gram/dl dan 0,001 gram/dl.

Berdasarkan nilai Adjusted $R$ Square sebesar 0,298 dapat diartikan bahwa sebesar 29,8\% kadar asam urat dipengaruhi oleh asupan protein hewani, vitamin $\mathrm{C}$ dan kalsium dan 70,2\% sisanya oleh variabel lain yang tidak diteliti.

\section{PEMBAHASAN}

Hiperurisemia adalah peningkatan kadar asam urat dalam darah lebih dari 7,0 mg/dl pada laki-laki dan lebih dari $6,0 \mathrm{mg} / \mathrm{dl}$ pada wanita. Angka tersebut merupakan batas kejenuhan asam urat dalam darah pada suhu $37^{\circ} \mathrm{C}$, bila kadar asam urat darah melebihi daya larutnya maka plasma darah menjadi sangat jenuh. ${ }^{2}$ Hiperurisemia yang terjadi dapat memicu terbentuknya timbunan kristal-kristal Monosodium Urate (MSU) pada sendi dan jaringan yang biasa disebut gout. ${ }^{20}$ Peningkatan kadar asam dalam darah dipengaruhi oleh berbagai faktor risiko, secara umum dapat diklasifikasikan akibat ekskresi melalui ginjal yang berkurang atau produksi yang berlebih namun sebagian besar hiperurisemia terjadi akibat penurunan ekskresi asam urat melalui ginjal dan biasa ditemukan pada wanita saat menopause. ${ }^{12}$

Menopause yang disebabkan hilangnya aktifitas folikel ovarium pada wanita umumnya terjadi pada usia 45-55 tahun. ${ }^{21}$ Usia subjek berada pada rentang 49-64 tahun, dimana sebanyak 37 orang berada pada rentang lansia muda $(54,4 \%)$. Adanya keterkaitan antara usia dan hiperurisemia ditunjukkan pada penelitian di Brazil tahun 2011 yang menemukan prevalensi hipeurisemia sebanyak $38 \%$ pada wanita usia $\geq 55$ tahun dan $32 \%$ sisanya pada wanita $<55$ tahun. Hiperurisemia akan terjadi pada wanita setelah menopause akibat adanya penurunan kadar estrogen yang berperan dalam peningkatan ekskresi asam urat melalui urin. ${ }^{5}$ Postmenopause merupakan fase klimaterik akhir dari menopause dimana pada fase ini terjadi adaptasi ovarium yang sudah tidak berfungsi lagi dan menjadi atrofi dengan kadar estradiol sebesar $<25 \mathrm{pg} / \mathrm{ml}$. Estradiol merupakan salah satu estrogen utama pada wanita yang berperan dalam peningkatan ekskresi asam urat melalui urin. ${ }^{21}$ Sehingga wanita postmenopause cenderung akan lebih berisiko mengalami hiperurisemia. Namun hasil penelitian hanya menemukan subjek hiperurisemia sebanyak 8 orang $(11,8 \%)$. Hal ini dapat dijelaskan oleh beberapa faktor lain yang berhubungan dengan kadar asam urat darah wanita postmenopause.

Asam urat merupakan produk akhir utama metabolisme purin yang merupakan bentuk turunan nukleoprotein baik berasal dari bahan makanan (eksogen) maupun dari hasil pemecahan purin asam nukleat dalam tubuh (endogen). ${ }^{23}$ Penguraian nukleotida purin berupa adenosine dan guanosin akan membentuk asam urat. Adenosine mula-mula mengalami deaminasi menjadi inosin yang kemudian akan mengalami degradasi menjadi hipoxantin, sedangkan guanosin berdegradasi membentuk guanine. Selanjutnya guanine dan hipoxantin akan membentuk xantin yang kemudian akan dikatalisasi oleh enzim xantin oksidase yang bekerja aktif didalam hati, usus halus dan ginjal membentuk asam urat. ${ }^{23}$ 
Diet tinggi protein diyakini dapat meningkatkan kadar asam urat darah. Hal tersebut ditunjukkan oleh penelitian Herlianty yang menyatakan bahwa konsumsi protein 56-110 gram/hari dapat memberikan risiko hiperurisemia $1,7 \mathrm{x}$ dan risiko hiperurisemia sebanyak $8,7 \mathrm{x}$ pada konsumsi protein $>110$ gram/hari. ${ }^{4}$ Namun uji Korelasi yang dilakukan, asupan protein total tidak memiliki hubungan yang signifikan dengan kadar asam urat darah wanita postmenopause (nilai $p$ value $=0,729 ; \mathrm{r}=0,43$ ), dimana sebagian besar subjek memiliki asupan protein total $\geq 57 \mathrm{gram} / \mathrm{hari}$ $(67,6 \%)$ dengan rerata asupan sebesar 75,79 gram/hari. Hasil yang sama ditunjukkan pada studi prospektif di Amerika Serikat tahun 2004 yang menyatakan bahwa asupan protein total tidak meningkatkan kadar asam urat darah. ${ }^{10} \mathrm{Hal}$ ini berkaitan dengan pemilihan bahan makanan sumber protein yang dikonsumsi. Diet tinggi protein diyakini berhubungan dengan peningkatan eksresi asam urat melalui urin dan dapat menurunkan kadar asam urat darah. Sebuah intervensi peningkatan asupan protein secara proporsional yang diberikan pada 13 orang pasien gout menunjukkan adanya penurunan yang signifikan pada frekuensi kejadian serangan gout pada pasien tersebut. ${ }^{22}$

Asupan protein sebagian besar subjek didapatkan dari sumber nabati. Berdasarkan hasil penelitian diketahui hanya 1 orang subjek yang memiliki asupan protein nabati cukup $(1,5 \%)$, sedangkan 67 orang subjek lainnya memiliki asupan tinggi $(98,5 \%)$. Protein nabati memiliki kadar purin rendah $<100 \mathrm{mg} / 100$ gram bahan makanan yang tidak memicu pemecahan purin berlebih. Meskipun hasil analisis bivariat menunjukkan tidak ada hubungan antara asupan protein nabati dengan kadar asam urat darah wanita postmenopause $(p$ value $=0,110 ; \mathrm{r}=-0,196$ ), namun studi di Amerika Serikat tahun 2005 menunjukkan penurunkan risiko terjadinya gout sebanyak $27 \%$ pada asupan protein nabati yang tinggi. ${ }^{10}$ Penderita hiperurisemia biasanya disarankan untuk mengurangi asupan purin yang berasal dari sumber protein hewani maupun protein nabati, namun berdasarkan temuan pada penelitian kohort selama 12 tahun yang menyarankan pembatasan asupan purin dari sumber hewani saja bagi penderita hiperurisemia. ${ }^{23}$

Berdasarkan penelitian diketahui sebanyak $72,1 \%$ subjek memiliki asupan protein hewani lebih dari anjuran yaitu 2-3 porsi sehari atau sebesar 14-21 gram/hari. Namun berdasarkan pemeriksaan kadar asam urat darah diketahui hanya 8 orang subjek yang mengalami hiperurisemia. Hal ini berkaitan dengan pemilihan bahan makanan sumber protein hewani yang dikonsumsi. Sumber protein hewani dikonsumsi disesuaikan dengan daya beli subjek, dimana sebagian besar memilih konsumsi telur dengan harga terjangkau. Konsumsi sumber protein hewani dengan kadar purin tinggi seperti daging dan seafood sangat jarang dilakukan dengan alasan ekonomi. Hasil wawancara Semi Quantitative Food Frequency menunjukkan subjek dengan hiperurisemia memang memiliki asupan bahan makanan sumber protein hewani tinggi purin dengan frekuensi 2-3x seminggu sebanyak 40-50 gram seafood dan 70-100 gram daging merah dalam satu kali makan.

Bahan makanan sumber protein hewani memiliki kandungan purin tinggi yang dapat meningkatkan kadar asam urat dalam urin sebesar $0,5-7,5 \mathrm{~g} / \mathrm{ml} .^{23}$ Hal ini sesuai dengan analisis bivariat yang menunjukkan adanya hubungan antara asupan protein hewani dan kadar asam urat darah wanita postmenopause ( $p$ value $=0,007 ; r=0,322$ ). Protein hewani merupakan salah satu sumber protein yang mengandung semua jenis asam amino esensial dalam proporsi sesuai kebutuhan sehingga memiliki bioavailabilitas atau daya cerna yang tinggi yaitu $90-99 \% .{ }^{24}$ Bioavailabilitas yang tinggi pada protein hewani menjadikannya banyak dipilih sebagai sumber protein dalam diet sehari-hari berupa ikan, daging, susu dan telur. Namun sebuah studi kohort selama 12 tahun pada pria menunjukkan adanya asupan daging dalam diet setiap hari dapat meningkatan risiko gout sebanyak $21 \%$, sedangkan asupan seafood dapat meningkatkan risiko sebanyak $7 \%$, dimana daging dan seafood memiliki kandungan purin antara 100$400 \mathrm{mg} / 100$ gram bahan makanan. ${ }^{22}$ Hal serupa ditunjukkan pada penelitian yang dilakukan di kota Batu, Malang pada tahun 2011 yang menunjukkan adanya pengaruh asupan protein hewani yang tinggi dengan risiko gout. ${ }^{25}$ Hasil penelitian menunjukkan semakin tinggi asupan protein khususnya protein hewani maka akan semakin tinggi pula kadar asam urat darah.

Penelitian di Korea tahun 2011 yang menemukan adanya asupan asam folat yang kurang pada penderita hiperurisemia. Studi yang sama menunjukkan adanya suplementasi asam folat sebesar $80 \mathrm{mg} / \mathrm{hari}$ dapat menurunkan kadar asam urat darah melalui penghambatan aktivitas enzim xantin oksidase yang berperan dalam produksi asam urat. ${ }^{15}$ Meskipun hasil uji Korelasi yang dilakukan menunjukkan tidak ada hubungan signifikan antara asupan asam folat dengan kadar asam urat darah $(p$ value $=0,506 ; \mathrm{r}=-0,082)$, namun diketahui bahwa sebagian besar subjek memiliki asupan asam folat cukup sesuai anjuran sebesar $150 \mu \mathrm{g} / \mathrm{hari}(63,2 \%)$. Semua subjek mendapatkan sumber asupan folat 
dari makanan seperti sayuran hijau dan kacangkacangan.

Vitamin C memiliki efek urikosurik yang dapat meningkatkan ekskresi asam urat dalam urin dengan berperan sebagai elektroaktif pengganggu oksidasi asam urat. ${ }^{26}$ Hasil penelitian menunjukkan sebagian besar subjek penelitian memiliki asupan vitamin C $\geq 75 \mathrm{mg} /$ hari $(66,2 \%)$. Sumber vitamin C yang banyak dikonsumsi berasal dari bahan makanan seperti jeruk, semangka, kubis, tomat serta sayuran hijau yang biasa digunakan setiap harinya. Selain dari bahan makanan, pemenuhan kebutuhan vitamin $\mathrm{C}$ beberapa subjek juga didapatkan melalui suplementasi. Hasil uji korelasi menunjukkan adanya hubungan antara asupan vitamin $\mathrm{C}$ dengan kadar asam urat darah wanita postmenopause $(p$ value $=0,010 ; \mathrm{r}=-0,311)$. Asupan vitamin $\mathrm{C}$ berhubungan negatif dengan kadar asam urat darah, artinya bahwa peningkatan asupan vitamin $\mathrm{C}$ dapat menurunkan kadar asam urat darah. Hal serupa ditemukan pada studi kohort di Amerika Serikat tahun 2008 yang menunjukkan suplementasi vitamin C sebesar $500 \mathrm{mg} /$ hari selama dua bulan dapat menurunkan kadar asam urat darah sebesar $0,5 \mathrm{mg} / \mathrm{dl} .{ }^{17}$ Asupan vitamin $\mathrm{C}$ yang tinggi baik dari makanan maupun suplementasi dapat meningkatkan laju filtrasi glomerulus yang akan meningkatkan sekresi asam urat melalui urin. ${ }^{27}$

Hasil penelitian menunjukkan $86,8 \%$ subjek memiliki asupan kalsium yang kurang. Hal ini berkaitan dengan peningkatan kebutuhan kalsium yang terjadi pada masa postmenopause. Beberapa penelitian menunjukkan bahwa penurunan kadar estrogen yang terjadi pada masa postmenopause berhubungan dengan kehilangan kalsium yang berlangsung cepat, sehingga memerlukan suplementasi kalsium yang adekuat. Selain itu berdasarkan riset WHO diketahui bahwa tingkat asupan kalsium masyarakat Indonesia hanya mencukupi 30\% dari kebutuhan yang dianjurkan sebesar 1000-1200 mg/hari. ${ }^{28}$ Uji korelasi menunjukkan adanya hubungan antara asupan kalsium dan kadar asam urat darah wanita postmenopause ( $p$ value $=0,014 ; \mathrm{r}=-0,295)$. Asupan kalsium memiliki hubungan negatif dengan kadar asam urat darah, dimana semakin tinggi asupan kalsium maka akan semakin rendah kadar asam urat darah wanita postmenopause. Sumber utama kalsium adalah susu dan hasil olahannya yang memiliki kadar purin rendah $<100 \mathrm{mg} / 100$ gram bahan makanan. Kalsium memiliki efek urikosurik dengan bertindak sebagai prekusor enzim xantin dalam mekanisme protein dan meningkatkan ekskresi asam urat. ${ }^{29}$ Studi yang dilakukan oleh NHANES III menunjukkan adanya kadar asam urat yang lebih rendah $0,5 \mathrm{mg} / \mathrm{dl}$ pada koresponden yang memiliki asupan kalsium tinggi. ${ }^{1}$

Anjuran asupan cairan minimal untuk lansia sebesar $1500 \mathrm{ml} / \mathrm{hari}$. Hasil penelitian menunjukkan konsumsi cairan rata-rata subjek sebanyak 1597,60 $\mathrm{ml} / \mathrm{hari}$. Pada penelitian ditemukan sebanyak 29 orang subjek dengan asupan cairan yang kurang. Hal ini dapat berkaitan dengan tingkat aktifitas fisik, suhu dan lingkungan serta usia, dimana sebagian besar usia subjek telah memasuki lansia muda dengan rerata usia 55,74 tahun. Pengatur utama intake cairan melalui mekanisme haus. Rangsangan haus berasal dari beberapa kondisi salah satunya adalah sekresi angiotensin II sebagai respon dari penurunan tekanan darah. Pada lansia terjadi perubahan hormonal dimana terdapat penurunan konsentrasi ginjal, renin, aldosteron, dan penurunan respon ginjal terhadap vasopressin, peningkatan kadar atrial natriuretic peptide (ANP) akan menyebabkan supresi sekresi renin ginjal, aktivitas renin plasma, angiotensin II plasma dan kadar aldosterone. ${ }^{30} \mathrm{Hal}$ tersebut berdampak pada penurunan rangsangan haus sehingga intake cairan pun akan menurun. Asupan cairan yang tinggi akan menurunkan reabsorpsi air di ginjal dan meningkatkan ekskresi berbagai zat terlarut termasuk asam urat. ${ }^{31}$ Hal yang sama ditunjukkan pada hasil analisis bivariat, dimana terdapat hubungan antara asupan cairan dengan kadar asam urat darah wanita postmenopause ( $p$ value $=0,007 ; \mathrm{r}=-0,322$ ). Temuan serupa didapat pada penelitian yang dilakukan pada 40 orang subjek wanita berusia 5060 tahun di Kecamatan Gajah Mungkur, Semarang yang menunjukkan adanya perbedaan kadar asam urat yang signifikan pada subjek dengan jumlah asupan purin yang sama namun memiliki jumlah asupan cairan yang berbeda. Subjek dengan asupan cairan $\geq 2000 \mathrm{ml}$ memiliki kadar asam urat yang lebih rendah dibandingkan dengan subjek yang memiliki asupan cairan $<2000 \mathrm{ml}$ setiap harinya. ${ }^{12}$

Uji Korelasi menunjukkan Indeks Massa Tubuh (IMT) tidak memiliki hubungan dengan kadar asam urat darah wanita postmenopause ( $p$ value $=0,865 ; \mathrm{r}=0,021)$. Namun berdasarkan hasil penelitian diketahui bahwa 8 orang subjek dengan hiperurisemia memiliki IMT lebih dari normal. Hal ini sesuai dengan hasil penelitian sebelumnya yang menunjukkan bahwa gout atau timbunan kristalkristal Monosodium Urate (MSU) yang dipicu hiperurisemia pada sendi dan jaringan banyak ditemukan pada penderita dengan kelebihan berat badan $30 \%$ dari berat ideal. Seiring terjadinya peningkatan berat badan maka sekresi asam urat akan meningkat sementara ekskresinya akan 
menurun..$^{32}$ Hasil penelitian menunjukkan sebanyak 29 orang subjek mengalami obesitas I $(42,6 \%), 21$ orang dengan status gizi overweight $(30,9 \%)$ dan hanya 10 orang dengan status gizi normal. Hasil temuan serupa ditemukan di Brazil tahun 2011 yang banyak menemukan adanya obesitas pada lansia. ${ }^{32}$ Hasil serupa juga ditemukan di India tahun 2012 yang menemukan adanya overweight dan obesitas masing-masing sebanyak $32,73 \%$ dan $30,65 \%$ pada wanita postmenopause, sementara pada wanita premenopause masing-masing hanya sebanyak $4,79 \%$ dan $12,57 \% .{ }^{33}$ Obesitas yang terjadi biasanya merupakan obesitas sentral akibat penurunan sekresi estrogen saat menopause. Penurunan sekresi estrogen tersebut dapat memicu perubahan distribusi lemak tubuh, dimana hipoestrogenisme tersebut memiliki pengaruh negatif terhadap metabolisme lemak dan menyebabkan penumpukan lemak secara bertahap pada jaringan viseral abdomen. ${ }^{6}$

Analisis multivariat menunjukkan bahwa protein hewani, vitamin $\mathrm{C}$, dan kalsium paling berhubungan terhadap kadar asam urat darah wanita postmenopause. Nilai Adjusted $R$ Square didapatkan sebesar 0,295 dengan persamaan untuk memprediksi kadar asam urat adalah $\mathrm{y}=5,634+$ 0,020 (asupan protein hewani) - 0,005 (asupan vitamin C) - 0,001 (asupan kalsium) dan dapat diartikan bahwa persamaan yang diperoleh mampu menjelaskan hiperurisemia sebesar $29,8 \%$, dan $70,2 \%$ sisanya dijelaskan oleh variabel lain yang tidak diteliti. Beberapa variabel lain yang dapat mempengaruhi kadar asam urat darah antara lain konsumsi alkohol, riwayat penyakit dan aktifitas fisik. Kebiasaan konsumsi alkohol khususnya bir yang memiliki kandungan guanosin tinggi diatas kadar moderat (1-2x/hari untuk pria dan $\leq 1 \mathrm{x} /$ hari untuk wanita) berhubungan dengan peningkatan risiko gout sebanyak $25-40 \%$. Konsumsi alkohol yang berlebihan akan meningkatkan kadar asam laktat yang merupakan produk samping dari metabolisme normal alkohol. Peningkatan asam laktat akan menyebabkan retensi dan penghambatan ekskresi asam urat oleh ginjal. ${ }^{34}$

Hiperurisemia memiliki hubungan dengan beberapa penyakit tertentu seperti displidemia, hipertensi, resistensi insulin dan bahkan penyakit jantung. Peningkatan kadar asam urat banyak terjadi pada kondisi resistensi insulin, dimana hiperinsulinemia dapat menurunkan sekresi asam urat melalui ginjal. Konsentrasi trigliserida yang tinggi dalam darah dapat menyebabkan hiperurisemia melalui sintesis asam lemak dalam hati yang berhubungan dengan sintesis de novo purin yang akan memproduksi asam urat. ${ }^{35}$ Asam urat dan hipertensi memiliki hubungan dimana asam urat dapat menghalangi bioavailabilitas dari nitrit oksid yang merupakan vasodilator dan meningkatkan tekanan darah. Hipertensi akan memicu penyakit pembuluh darah dan meningkatkan resistensi pembuluh darah hati yang akan meningkatkan resorbsi asam urat. ${ }^{36}$ Adanya gangguan fungsi ginjal juga dapat berpengaruh pada peningkatan kadar asam urat darah. Ginjal merupakan organ tubuh yang berperan dalam pembuangan sisa-sisa metabolisme dan zat-zat lain yang sudah tidak dibutuhkan oleh tubuh termasuk asma urat dari metabolisme asam nukleat. Gangguan fungsi ginjal akan menurunkan sekresi asam urat melalui urin dan mempengaruhi pengaturan kadar asam urat normal dalam darah. Asam urat yang seharusnya dikeluarkan akan terolah lagi oleh tubuh sehingga konsentrasinya akan meningkat dan bila berlangsung lama dapat menyebabkan timbunan kristal MSU pada sendi dan jaringan. ${ }^{37}$ Konsumsi alkohol dan riwayat penyakit dijadikan sebagai kriteria eksklusi sehingga pengaruh variabel lain tersebut telah terkontrol pada subjek.

Aktifitas fisik yang rendah menjadi salah satu penyebab terjadinya obesitas yang dapat memicu terjadinya hiperurisemia. Seseorang dengan berat badan berlebih memiliki risiko hiperurisemia yang berkaitan dengan peningkatan kadar asam urat dan penurunan sekresinya melalui ginjal. $^{38}$ Adanya obesitas dapat merujuk pada perkembangan beberapa penyakit metabolik yang juga dapat memicu hiperurisemia dan perkembangan penyakit gout, sehingga penting untuk melakukan peningkatan aktifitas fisik dalam membantu pencegahan hiperurisemia. Meskipun aktifitas fisik tidak diteliti pada penelitian ini, namun diketahui bahwa sebagian besar subjek memiliki kebiasan olahraga 1-3 kali seminggu dikarenakan terdapat kelompok senam lansia aktif yang menyelenggarakan senam lansia rutin 2-3 kali seminggu dan sebagian besar subjek merupakan anggota kelompok tersebut.

\section{SIMPULAN}

Rerata usia subjek 55,74 tahun dengan subjek hiperurisemia ditemukan sebanyak 8 orang $(11,8 \%)$. Asupan protein (protein total, protein hewani, dan protein nabati) subjek sebagian besar lebih dari anjuran angka kecukupan gizi sehari. Sebagain besar asupan asam folat, vitamin $\mathrm{C}$ dan cairan subjek sudah cukup, namun memiliki asupan kalsium yang kurang. Asupan protein hewani yang berlebih dan asupan vitamin $\mathrm{C}$, kalsium serta cairan yang kurang berhubungan dengan peningkatan 
kadar asam urat darah $(p<0,05)$. Asupan yang paling berpengaruh dengan kadar asam urat darah wanita postmenopause adalah asupan protein hewani, vitamin $\mathrm{C}$ dan kalsium.

\section{SARAN}

Hiperurisemia dapat dicegah dengan perubahan gaya hidup meliputi pengaturan pola makan yang baik, seperti konsumsi protein hewani sesuai anjuran 2-3 porsi sehari yang diimbangi dengan pemenuhan asupan vitamin $\mathrm{C}$ sebesar 75 $\mathrm{mg} /$ hari, kalsium yang cukup 1000-1200 mg/hari, dan konsumsi cairan yang cukup $>1500 \mathrm{ml} / \mathrm{hari}$, serta meningkatkan aktifitas fisik.

\section{DAFTAR PUSTAKA}

1. Zhu Y, Pandya BJ, Choi HK. Prevalence of Gout and Hyperuricemia in the US General Population. The National Health and Nutrition Examination Survey 2007-2008. Arthritis and Rheumatism, October 2011: 63(10): p3136-3141.

2. Luk JA, Simkin PA. Epidemiology of hyperuricemia and gout. The American Journal of Managed Care.2005;11:436-442

3. Putra Tjokarda R. Hiperurisemia. Dalam: Ilmu penyakit dalam jilid 2. Edisi 4. Jakarta: Departemen Ilmu Penyakit Dalam Fakultas Kedokteran Universitas Indonesia; 2006;p.203-1206.

4. Herlianty MP. Faktor gizi sebagai determinan hiperurisemia. Konas XII Persagi. Persatuan Ahli Gizi Indonesia.2002.hal.152-155

5. Mahajan A, Tandon VR, Sharma S, Jandial C. Gout and menopause JK Science Jan-Marc 2007;9;50-51

6. Gravena AF, Brischiliari RC, Lopes CR, Agnolo MD, Carvalho DB, Pelloso SM. Excess weight and abdominal obesity in postmenopausal Brazilian women; a population based study. BMC Women's Health. 2013

7. Choi HK,Mount DB, Reginato AM. Pathogenesis of gout. Ann Intern Med 2005; 143:499-516

8. Villegas R, Xiang YB, Elasy T, Cai H, Linton MF, et al. Purine-rich foods, protein intake, and the prevalence of hyperuricemia: the Sanghai men's health study. Elsevier 2012;22:409-416

9. Kalim H, Sunarti S, Anindhita P. Identifikasi hubungan pola asupan protein hewani dengan resiko gout arthritis di kota Batu. Program Faculty of Medicine Brawijaya University Malang. 2011

10. Choi HK, Liu S, Curhan G. Intake purine-rich foods, protein, and dairy products and relationship to serum levels of uric acid: the Third National Health and Nutrition Examination Survey. Arthritis \& Rheumatism. 2005;52:283-289

11. Gout [editorial]. The Patient Educational Institute Inc 1995-2011

12. Diantari, E. Pengaruh Asupan Purin dan Cairan Terhadap Kadar Asam Urat Wanita Usia 50-60 tahun di Kecamatan Gajah Mungkur, Semarang. [Skripsi]. Semarang: FKUNDIP; 2012
13. Schmidt JA, Crowe FL, Appleby PN, Key TJ, Travis RC. Serum uric acid concentration in meat eaters, fish eaters, vegetarians and vegans: a crosssectional analysis in the EPIC-Oxford Cohort. PLoS ONE. 2013; 8(2):e56339

14. Zgaga L, Theodoratou E, Kyle J, Farrington SM, Agakov F, etc. The association of dietary intake of purine-rich vegetable, sugar sweetened beverages and dairy with plasma urate in a cross-sectional study. PLoS ONE. 2012; 7(6):e38123

15. Ryu KA, Kang HH, Kim SY, Yoo MK, Kim JS, Lee $\mathrm{CH}$, Wie GA. Comparison of nutrient intake and diet quality between hyperuricemia subjects and controls in Korea. Clin Nutr Res 2014;3:56-63

16. Kumala M. Peran gizi dalam penatalaksanaan hiperurisemia dan pirai. Damianus Jurnal of Medicine Jun 2010;9 (2): 121-128

17. Gao X, Curhan G, Forman JP, Ascherio A, Choik HK. Vitamin $C$ intake and serum uric acid concentration in Men. J Rehumatol. 2008; 35(9):1853-1858

18. Chernoff, Roni. Geriatric Nutrition the health professional's Handbook. Boston: Jones and Bartlett publishers; 2006.p.26-28

19. Sugondo S. Obesitas. Dalam: Ilmu penyakit dalam jilid 3. Edisi 4. Jakarta: FKUI; 2006;p.1919-1925.

20. Doherty M. New insights into the epidemiology of gout. Rheumatology. 2009;48:ii2-ii8

21. Burger H, Dudley E, Robertson D, Dennerstein L. Hormonal changes in menopause transition. The Endocrine Society. 2005

22. Dessein PH, Shipton EA, Stanwix AE, Joffe BI, Ramokgadi J. Beneficial effects of weight loss associated with moderate calorie/ carbohydrate restriction, and increased proportional intake of protein and unsaturated fat on serum urate and lipoprotein lev els in gout: a pilot study. Ann Rheum Dis. 2000;59:539-43.

23. Choi HK, Atkinson K, Karlson EW, Willett W, Curhan G. Purine-rich foods, dairy and protein intake, and the risk of gout in men. $\mathrm{N}$ Engl J Med. 2004; 350: 1093-103

24. Kusindarti S. Penatalaksanaan Diet Rendah Purin. Media Dietetik. Edisi Khusus 2002. Asosiasi Dietitien Indonesia; 2002:9-15

25. Kalim H, Sunarti S, Anindhita P. Identifikasi hubungan pola asupan protein hewani dengan resiko gout arthritis di kota Batu. Program Faculty of Medicine Brawijaya University Malang. 2011

26. Gao X, Curhan G, Forman JP, Ascherio A, Choi HK. Vitamin $C$ intake and serum uric acid concentration in Men. J Rehumatol. 2008; 35(9):1853-1858

27. Kensarah O, Azzeh F. Implementing high vitamin $\mathrm{C}$ treatments to decrease blood uric acid levels in hyperuricemic Saudi patients. Journal of American Science. 2012;8(5)

28. Weitzmann MN, Pacifici R. Estrogen deficiency and bone loss: an inflammatory tale. J Clin Invest. 2006;116(5):1186-1194 
29. Schmidt JA, Crowe FL, Appleby PN, Key TJ, Travis RC. Serum uric acid concentration in meat eaters, fish eaters, vegetarians and vegans: a crosssectional analysis in the EPIC-Oxford Cohort. PLoS ONE. 2013; 8(2):e56339

30. Charney P. Water, Electrolytes and Acid-Base Balance. In: Mahan LK, Stumps SE, editors. Krause's food, nutrition $\&$ diet therapy. $11^{\text {th }}$ edition. Philadeplhia: Saunders; 2008. P.144

31. Chang A, Kramer H. Fluid intake for kidney disease prevention : an urban myth?. Clin J Am Soc Nephrol. 2011; 6 : 2558-2560

32. Poletto J, Harima HA, Ferreira SR, Gimeno SG Hyperuricemia and associated factors: a crosssectional study of Japanese-Brazillians. Cad. Saude Publica. 2011; 27(2):369-378

33. Singh V, Sahu M, Yadav S, Harris KK. Incidence of obesity among the pre-menopausal and postmenopausal working women of Raipur district (Chhattisgarh State). World Journal of Science and Technology. 2012; 2(6): 83-86

34. Saag KG, Choi HK. Epidemiology, risk factors, and lifestyle modification for gout. Arthritis Research \& Therapy. 2006;8(Suppl 1):S2

35. Matsubara, Miyao, Hitoshi Chiba, Shoji Marouka, Shinki Katayose, Elevated Serum Leptin Concentration in Women with Hyperuricemia, Journal of Atherosclerosis and Thrombosis, 2002, 9:28-34.

36. Putra TR. Hiperurisemia. Dalam: Sudoyo AW, editors. Buku ajar ilmu penyakit dalam jilid II. Edisi IV. Jakarta: PP Departemen Ilmu Penyakit Dalam FKUI;2006.p 1023-7

37. Murray RK, Granner DK, Rodwell VW. Biokimia Harper edisi 27. (alih bahasa: dr. Brahm U. Pendit). Jakarta: Penerbit Buku Kedokteran EGC; 2006

38. Choi HK, Atkinson K, Karlson EW, Curhan G. Obesity, weight change hypertension, diuretic use, and risk of gout in men: the health profesionals follows-up study. Arch Intern Med 2005; $11: 165: 742-8$ 